\title{
PENINGKATAN PEMAHAMAN PERSONALIA PT. ASIA FORESTAMA RAYA PEKANBARU: PENYELESAIAN PERSELISIHAN HUBUNGAN INDUSTRIAL
}

\author{
Zulkarnaen Noerdin*1, Robert Libra ${ }^{2}$, Rizana $^{3}$ \\ 1,2,3Program Studi Ilmu Hukum, Fakultas Hukum, Universitas Lancang Kuning \\ e-mail: robertlibra87@gmail.com
}

\begin{abstract}
The need for understanding the existence of Industrial Relations Dispute Resolution (PPHI) based on Law Number 2 of 2004 concerning PPHI is very urgent in the company. There are a lot of workers and company personnel who do not / do not know about the existence of this regulation, if there are problems in the industrial field, the workers do not know the existing regulations, including understanding so that no disputes occur The solutions offered by the team are lectures, dialogues and discussions to solve the problems faced. The work procedures to support the methods offered are lectures held 1 (one) hour, and dialogues and discussions for 2 hours or according to the needs of partners as long as they are within the period of implementation of this program. The participation of partners in the community service program is to provide the place and time for program implementation and to present partner members as audiences. The output that will be produced according to the plan of community service activities is: for partners, of course, increased understanding of the Industrial Relations Dispute Settlement (PPHI) based on Law Number 2 of 2004 concerning PPHI. For the outcome proposals to be achieved are scientific articles and cannot be separated from the Tri Darma of Higher Education.
\end{abstract}

Keywords - Increased Understanding, Settlement of Industrial Relations Disputes (PPHI)

\begin{abstract}
Abstrak
Kebutuhan tentang pemahaman mengenai adanya Penyelesaian Perselisihan Hubungan Industrial (PPHI) berdasarkan Undang-undang Nomor 2 tahun 2004 tentang PPHI sangatlah Urgent Di Perusahaan. Banyak sekali Tenaga Kerja dan Personalia Perusahaan yang tidak/belum mengetahui tentang adanya Regulasi ini, apabila ada masalah dalam bidang Industrial Tenaga Kerja tidak mengetahui peraturan yang ada, termasuk pemahaman supaya tidak terjadi perselisihan. Solusi yang ditawarkan tim adalah ceramah, dialog dan diskusi memecahkan masalah-masalah yang dihadapi. Adapun prosedur kerja untuk mendukung metode yang ditawarkan adalah ceramah dilaksanakan 1 (satu) jam, dan dialog serta diskusi selama 2 jam atau sesuai kebutuhan mitra sepanjang masih dalam jangka waktu pelaksanaan program ini. Partisipasi mitra dalam acara pengabdian kepada masyarakat ini adalah menyediakan tempat dan waktu pelaksanaan program serta menghadirkan anggota mitra sebagai audien. Luaran yang akan dihasilkan sesuai rencana kegiatan pengabdian kepada masyarakat ini adalah: bagi mitra tentunya peningkatan pemahaman terhadap Penyelesaian Perselisihan Hubungan Industrial (PPHI) berdasarkan Undang-undang Nomor 2 tahun 2004 tentang PPHI. Bagi pengusul luaran yang akan dicapai adalah berupa artikel ilmiah dan tidak terlepas juga dari Tri Darma Perguruan Tinggi
\end{abstract}

Kata kunci-Peningkatan Pemahaman, Penyelesaian Perselisihan Hubungan Industrial (PPHI)

\section{PENDAHULUAN}

PT. Asia Forestama Raya Pekanbaru merupakan salah satu perusahaan di Kota Pekanbaru Provinsi Riau yang bergerak dibidang Pengolahan Kayu Lapir dan memiliki karyawan yang cukup banyak. Kebutuhan tentang Peningkatan Pemahaman Bidang Personalia PT. Asia Forestama Raya Pekanbaru tentang Penyelesaian Perselisihan Hubungan Industrial. merupakan hal yang sangat 
urgent. Bidang Personalia Manajemen perusahaan membutuhkan pemahaman karena banyaknya Kasus Perusahaan sebagai tergugat di Pengadilan Hubungan Industrial Pekanbaru dan banyaknya laporan dari karyawan terkait permasalahan Hubungan Industrial dengan pihak PT. Asia Forestama Raya Pekanbaru sehingga mempengaruhi keamanan, kelancaran dan eksistensi Perusahaan kedepan maka dari itu upaya preventif harus dilakukan dengan mendatangakan ahli. Ketika keadaan perusahaan tidak aman dan tertip maka ini sangat menggganggu sekali, sementara Tujuan Hukum Ketenagakerjaan Menurut ahli Manullang adalah sebagai berikut:

a. Untuk mencapai dan melaksanakan keadilan sosial dalam bidang ketenagakerjaan. (menjaga ketertiban, keamanan dan keadilan bagi pihak-pihak yang terkait dalam proses produksi, untuk dapat mencapai ketenangan bekerja dan kelangsungan berusaha).

b. Untuk melindungi tenaga kerja terhadap kekuasaan yang tidak terbatas dari pengusaha. (dilatar belakangi adanya pengalaman yang sering sekali terjadi kesewenang-wenangan pengusaha terhadap pekerja/buruh).

Amanat dalam Pasal 4 Undang-undang Nomor 13 Tahun 2003 tentang Ketenagakerjaan yang menyatakan:

a) Memberdayakan dan mendayagunakan tenaga kerja secara optimal dan manusiawi.

b) Mewujudkan pemerataan kesempatan kerja dan penyediaan tenaga kerja sesuai dengan pembangunan nasional dan daerah.

c) Memberikan perlindungan kepada tenaga kerja dalam mewujudkan kesejahteraan.

d) Meningkatkan kesejahteraan tenaga kerja dan keluarganya.

Tenaga kerja hendaknya memahami tuntutannya bahwa peningkatan kesejahteraan mutlak harus diimbangi dengan peningkatan produktifitas. Produk manufakturing dan atau jasa yang dihasilkan oleh tenaga kerja rendah tentu perusahaan akan merugi dan kesulitan untuk dapat memberikan kesejahteraan yang layak atau hak normatif kepada para tenaga kerja, jika kondisi seperti ini terjadi terus menerus lambat laun perusahaan akan runtuh dan dinyatakan pailit, sehingga dapat menmbulkan dampak yang sangat besar bagi banyak pihak yang berkepentingan khususnya para tenaga kerja (Armida S Alisyahbana, Hal 8).

Hasil Wawancara dengan Bapak Jamal Wakil Manajemen PT. Asia Forestama Raya Pekanbaru menagatakan banyaknya kasus perselisihan hubungan industrial yang terjadi di perusahaan mengakibatkan terganggunya proses produksi dan keamanan berusaha maka dari itu harus cepat diberikan solusi untuk mengatasi masalah ini. (Hasil Wawancara dengan Bapak Jamal Wakil Manajemen pada tanggal 20 Agustus 2018 di PT. Asia Forestama Raya Pekanbaru).

Dari pemaparan pada analisis situasi di atas maka yang menjadi permasalahan mitra di dalam Pengabdian Kepada Masyarakat ini adalah Mitra kurang paham tentang Penyelesaian Perselisihan Hubungan Industrial (PPHI) berdasarkan Undang-undang Nomor 2 tahun 2004 tentang PPHI.

\section{METODE}

Permasalahan yang dihadapi mitra adalah, Mitra kurang memahami tentang Penyelesaian Perselisihan Hubungan Industrial. Dengan adanya kegiatan ini Mitra akan dapat meningkatkan pemahaman dan mencegah timbulnya perselisihan di lingkungan Dunia Kerja perusahaan tersebut. Metode pendekatan pelaksanaan kegiatan pengabdian kepada masyarakat ini adalah dengan menggunakan metode ceramah, dialog, dan diskusi dengan jumlah masyarakat 30 (tiga puluh) orang, dalam rangka penyuluhan hukum atau membedah Penyelesaian Perselisihan Hubungan Industrial.

Partisipasi mitra dalam penyelenggaraan kegiatan ini adalah menyediakan tempat pelaksanaan, mengundang perwakilan karyawan yang membutuhkan pemahaman dan memfasilitasi semua pelaksanaan kegiatan ini.

Evaluasi dilakukan dengan membagikan kuesioner sebelum dan sesudah kegiatan dilaksanakan untuk mengukur tingkat pemahaman masyarakat terhadap proses untuk mendapatkan bantuan hukum. Untuk evaluasi keberhasilan pelaksanaan kegiatan pegabdian pada masyarakat ini adalah diukur dari antusias peserta yang mengikuti kegiatan ini dan banyaknya pertanyaan-pertanyaan yang diajukan oleh para peserta. 


\section{HASIL DAN PEMBAHASAN}

Kegiatan Pengabdian kepada masyarakat ini telah dilaksanakan pada hari Kamis tanggal 13 Desember 2018 bertempat di Aula PT. Asia Forestama Raya Rumbai Pekanbaru. Kegiatan ini dimulai Pukul 14.00 WIB sampai dengan 16.00 WIB. Jumlah peserta yang hadir adalah sebanyak 30 orang. Hadir pada kegiatan penyuluhan hukum ini adalah Ketua Asosiasi Pengusaha Indonesia Pekanbaru Bapak Dr. Fahrial, S.E..

Dalam pelaksanaan kegiatan ini para peserta sangat antusias dalam mengikuti rangkaian acara hingga selesai, hal ini dapat dilihat saat sesi dialog tanya jawab antara peserta dengan nara sumber. Dari pertanyaan-pertanyaan yang dilontarkan oleh peserta dapat diambil kesimpulan bahwa adanya hasil transfer ilmu pegetahuan kepada khalayak sasaran sesuai dengan yang direncanakan oleh tim pengadian kepada masyarakat. Antusias peserta dalam mengikuti kegiatan ini juga dapat dilihat dari adanya Makanan dan Minuman yang disediakan oleh peserta kepada tim pengabdian masyarakat.

Sebagaimana permasalahan prioritas pihak mitra kurangnya pengetahuan dan pemahaman mengenai Penyelesaian Perselisihan Hubungan Industrial. Fenomena yang muncul pada saat pelaksanaan kegiatan berlangsung Berdasarkan hasil interaktif dan respon khalayak sasaran, muncul suatu permasalahan yang dialami beberapa khalayak diantaranya, pertama, ada yang sudah 3 bulan upah belum dibayar oleh pengusaha, kedua, upah yang dibayarkan pengusaha dibawah ketentuan upah minimum Provinsi Riau, maka pihak pengabdi menjawab keduanya sesuai dengan peraturan pemerintah nomor 78 tahun 2015 tentang pengupahan dan untuk tahun 2019 sudah ada ketentuan baru mengenai Upah Minimum Provinsi Riau.

Berdasarkan hasil yang diperoleh dari kegiatan ini para peserta telah merasakan manfaatnya, yaitu mendapat tambahan pengetahuan dan pemahaman mengenai Penyelesaian Perselisihan Hubungan Industrial (PPHI) berdasarkan Undang-undang Nomor 2 tahun 2004 tentang PPHI. Hal itu disimpulkan tim pengabdian kepada masyarakat setelah membandingkan hasil tes awal (pre test) dan tes akhir (post test) dengan cara mengajukan kuisioner sebelum dan sesudah pemberian materi.

Sebelum pemberian tes awal tersebut khalayak sasaran atau para peserta banyak yang tidak mengetahui dan memahami tentang Penyelesaian Perselisihan Hubungan Industrial (PPHI) berdasarkan Undang-undang Nomor 2 tahun 2004 tentang PPHI. Setelah dilakukan pengabdian kepada masyarakat dengan pemberian materi yang tepat maka khalayak sasaran pada umumnya mampu menjawab dengan benar pertanyaan-pertanyaan di dalam kuisioner yang diajukan setelah pelaksanaan kegiatan. Dengan demikian, kegiatan pengabdian kepada masyarakat ini dapat dikatakan telah berhasil dengan indikator perbandingan hasil tes awal (pre test) dan tes akhir (post test) kepada khalayak sasaran. Pelaksanaan kegiatan pengabdian kepada masyarakat ini dapat dikatakan tidak dijumpai hambatan dengan dihadiri oleh Tenaga Kerja, Personalia Perusahaan, dan unsur Wakil Manajemen Perusahaan karena tema yang diangkat cukup menarik dan relevan dengan apa yang dibutuhkan pihak mitra saat ini.

Keberhasilan pelaksanaan kegiatan pengabdian ini dapat dilihat berdasarkan tabel hasil kuisioner pre-test dan post-test berikut:

\section{Hasil Kuisioner Pre-Test dan Post-Test}

\begin{tabular}{|c|c|c|c|}
\hline NO. & PERTANYAAN & $\begin{array}{c}\text { JAWABAN KUISIONER } \\
\text { AWAL }\end{array}$ & $\begin{array}{c}\text { JAWABAN KUISIONER } \\
\text { AKHIR }\end{array}$ \\
\hline 1. & $\begin{array}{l}\text { Dasar Hukum tentang PPHI } \\
\text { tenaga kerja di indonesia } \\
\text { diatur dalam................... } \\
\text { A. PP No. } 78 \text { tahun } 2015 \\
\text { B. UU No. } 2 \text { Tahun } 2004 \\
\text { C. UU. No. } 3 \text { Tahun } 1992\end{array}$ & $\begin{array}{lrl}\text { A. } & 10 & =33 \% \\
\text { B. } & 17 & =57 \% \\
\text { C. } & 3 & =10 \%\end{array}$ & $\begin{array}{l}\text { A. } \quad 30=100 \% \\
\text { B. } \quad 0=0 \% \\
\text { C. } \quad 0=0 \%\end{array}$ \\
\hline
\end{tabular}

Kunci: B 


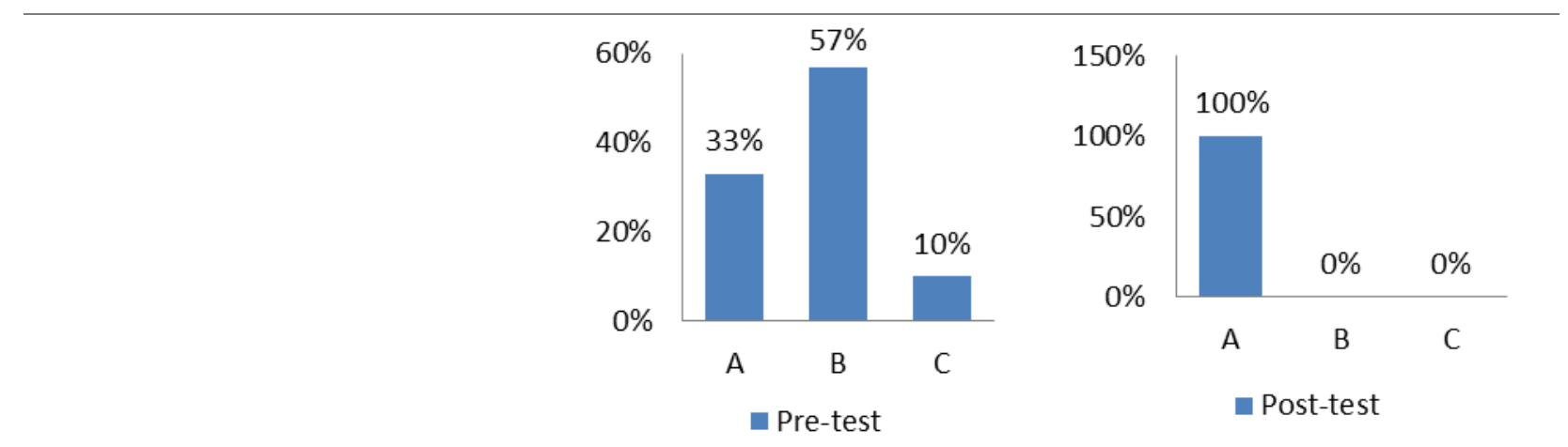

2. Dasar Hukum Tentang

Tenaga Kerja di

Indonesia...

A. PP No. 78 tahun 2015

B. UU No. 2 Tahun 2004

C. UU. No. 13 Tahun 2003

Kunci: C $\begin{array}{lrl}\text { A. } & 5 & =17 \% \\ \text { B. } & 20 & =66 \% \\ \text { C. } & 5 & =17 \%\end{array}$

$30 \%$

$20 \%$

$20 \%$

$10 \%$

$0 \%$

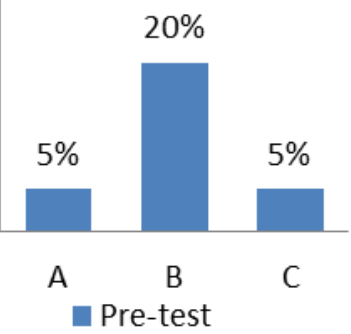
A. $0=0 \%$
B. $1=3 \%$
C. $29=97 \%$

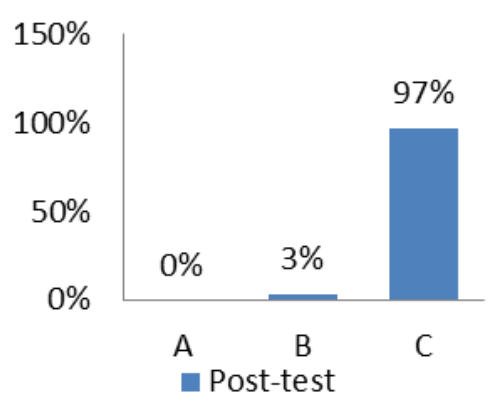

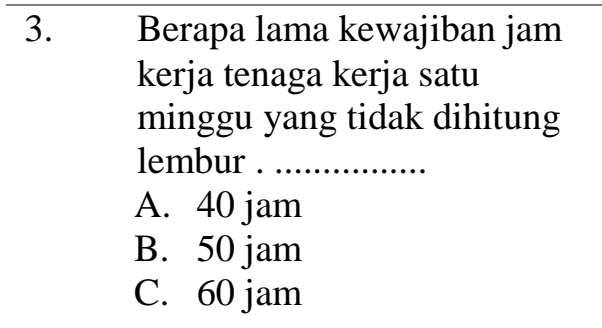

Kunci: A
A. $13=44 \%$
A. $30=100 \%$
B. $10=33 \%$
B. $0=0 \%$
C. $7=23 \%$
C. $0=0 \%$
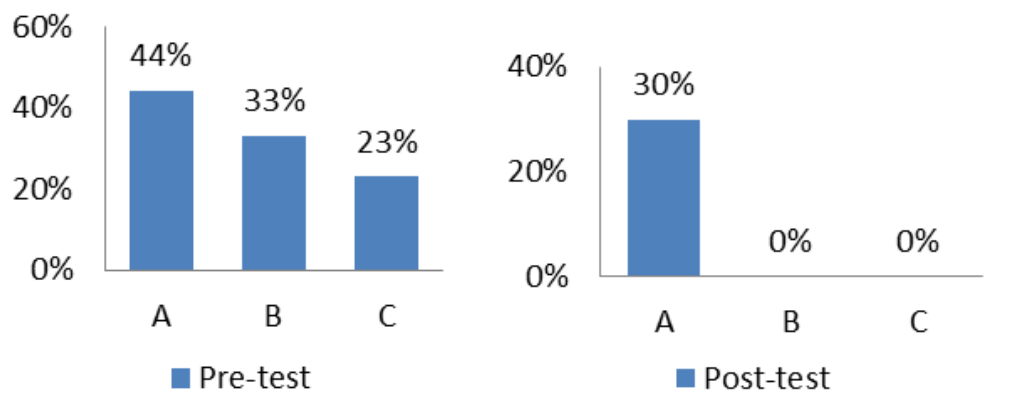

4. Yang termasuk perselisihan hubungan industrial,

A. $7=23 \%$

B. $10=33 \%$ kecuali......

C. $13=44 \%$
A. Hak
B. Upah
C. PHK

Kunci: B

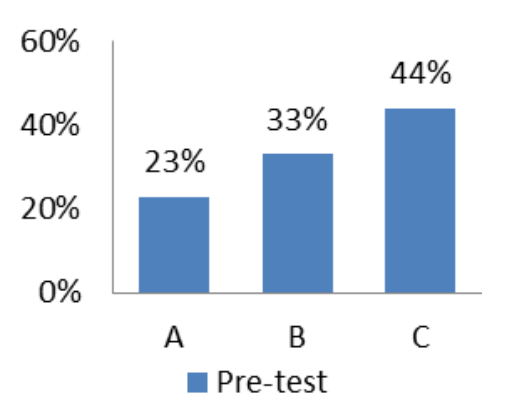
A. $0=0 \%$
B. $30=100 \%$
C. $0=0 \%$
A. $15=50 \%$
A. $6=20 \%$
B. $5=17 \%$
B. $22=73 \%$
C. $10=33 \%$
C. $2=7 \%$

ketenagakerjaan di

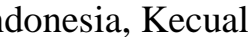
adalah... 
$\begin{array}{ll}\text { A. } & \text { UU. No. } 2 \text { Tahun } 2004 \\ \text { B. UU. No. } 1 \text { Tahun } 1974 \\ \text { C. UU. No. } 13 \text { tahun } 2003\end{array}$

Kunci: B

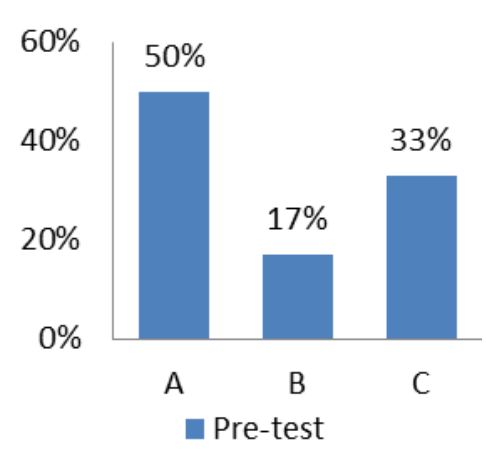

Sumber Data : Desember 2018

Memperhatikan data pada tabel di atas nampak bahwa sebelum pemberian materi khalayak sasaran atau para peserta banyak yang belum mengetahui hal-hal yang telah di atur oleh Penyelesaian Perselisihan Hubungan Industrial (PPHI) berdasarkan Undang-undang Nomor 2 tahun 2004 tentang PPHI.

Setelah pemberian materi terjadi peningkatan pengetahuan dan pemahaman khalayak sasaran berkisar antara $60 \%$ sampai dengan $65 \%$ dari sebelumnya, karena pada umumnya mereka memilih jawaban yang benar sebagaimana dapat dilihat pada tabel pre test dan post test diatas.

Luaran yang dicapai dan diharapkan dari kegiatan pengabdian ini adalah setelah khalayak sasaran meningkat pengetahuan dan pemahamannya tentang Pengupahan dan ketenagakerjaan di Indonesia, maka permasalahan yang terjadi pada Tenaga Kerja tentang Penyelesaian Perselisihan Hubungan Industrial (PPHI) berdasarkan Undang-undang Nomor 2 tahun 2004 tentang PPHI bisa terselesaikan dengan baik sesuai regulasi yang ada.

\section{KESIMPULAN}

Persoalan prioritas yang dihadapi khalayak sasaran atau pihak mitra sebelum pemberian materi yaitu khalayak sasaran atau pihak mitra tidak mengetahui dan memahami mengenai Penyelesaian Perselisihan Hubungan Industrial (PPHI) berdasarkan Undang-undang Nomor 2 tahun 2004 tentang PPHI.

Perubahan dan peningkatan pengetahuan serta pemahaman khalayak sasaran terjadi secara signifikan berkisar antara $70 \%$ sampai dengan $75 \%$ setelah pemberian materi oleh tim pengabdi sesuai dengan solusi yang disepakati dengan pihak mitra, yakni pengupahan dan hak-hak lain dalam bidang ketenagakerjaan.

\section{SARAN}

Sebaiknya pengetahuan dan pemahaman masyarakat yang didapat dari kegiatan pelaksanaan pengabdian kepada masyarakat dengan tema ini :

1. Dapat di implemetasikan oleh pihak khalayak sasaran atau pihak mitra secara benar dan bijak pada masalah yang sedang dihadapi.

2. Pelaksanaan pengabdian masyarakat ini sebaiknya tetap dilanjutkan dengan tema yang sama dengan khalayak sasaran sejenis karena tidak tertutup kemungkinan masih banyak tenaga kerja dan Personalia Perusahaan yang menghadapi problem yang sama.

3. Perlu adanya kerjasama kemitraan antara kelurahan dengan pemerintah dan instansi lainnya yang peduli dengan nasib tenaga kerja di indonesia.

\section{DAFTAR PUSTAKA}

[1] Armida S. Alisyahbana,et.al, 2004, Indonesia's Employment Protection Legislation, Swimming Against the Tide, UNPAD, Bandung. 
[2] John Rawls, A Theory of Justice, London: Oxford University press, 1973, terjemahan dalam bahasa indonesia oleh Uzair Fauzan dan Heru Prasetyo, Teori Keadilan, Yogyakarta: Pustaka Pelajar, 2006

[3] Undang Undang Dasar Negara Republik Indonesia Tahun 1945.

[4] Undang undang Nomor 13 tahun 2003 tentang Ketenagakerjaan.

[5] Undang-undang Nomor 2 Tahun 2004 tentang Penyelesaian Hubungan Industrial.

[6] Himpunan Peraturan Perundang-undangan Norma Ketenagakerjaan, 2010 Kementerian Tenaga Kerja dan Transmigrasi, Direktorat Binwasnaker. 